\title{
Correspondance
}

\section{Peer review of articles on global burden of disease}

$\mathrm{P}$ aula Rochon and associates ${ }^{1}$ call for a better reflection of the global burden of disease in clinical trials published in leading general medical journals. In extending their coverage to global health issues, large Western medical journals may have difficulties in finding reviewers from countries with small research communities. We surveyed $236(63.8 \%)$ of the tenured faculty members at 4 medical schools in Croatia, a small country with disease burden related to war and post-communist socioeconomic transition, ${ }^{2}$ about their willingness to review for a large journal, such as The Lancet, and the small Croatian Medical fournal, as well as the criteria they would use in reviewing manuscripts. ${ }^{3}$ More than half of the respondents (126 or 53.4\%) had not published in either journal, and only $10(4.2 \%)$ had published in both journals. A few respondents (23 or $9.7 \%$ ) were not interested in reviewing for either journal, and only a single person expressed a desire to review for The Lancet but not the Croatian Medical fournal (Table 1). A surprising 169 (71.6\%) of the respondents said they would review only for the Croatian Medical fournal, and a further 43 $(18.2 \%)$ that they would review for both journals. Most respondents stated that, if they were to serve as reviewers, they would be equally strict for both journals or would perform a stricter review for The Lancet (Table 1). Respondents who wanted to review for The Lancet were generally less experienced reviewers who read that journal but who thought that reviewers' recommendations were not important for editorial decisions.

Our survey results are valid only for Croatia but may be indicative of the beliefs of researchers in other less developed research communities. These results indicate that bridging the publishing gap between the global burden of disease and Western medical journals may not be so easy, and those journals should therefore become active in building research and publishing

\begin{tabular}{|c|c|c|}
\hline Survey question & $\begin{array}{r}\text { No } \\
\text { or me }\end{array}$ & $\begin{array}{l}d \%) \\
\text { and SD) }\end{array}$ \\
\hline \multicolumn{3}{|l|}{ Willingness to review } \\
\hline Neither CMJ nor The Lancet & 23 & $(9.7)$ \\
\hline CMJ only & 169 & $(71.6)$ \\
\hline The Lancet only & 1 & $(0.4)$ \\
\hline Both & 43 & $(18.2)$ \\
\hline \multicolumn{3}{|l|}{ Review criteria } \\
\hline Equally strict for both journals & 193 & $(81.8)$ \\
\hline Stricter for The Lancet & 42 & $(17.8)$ \\
\hline Stricter for $C M J$ & 1 & $(0.4)$ \\
\hline \multicolumn{3}{|l|}{$\begin{array}{l}\text { Understanding and experience } \\
\text { of peer review* }\end{array}$} \\
\hline $\begin{array}{l}\text { Peer review is important for editorial } \\
\text { decisions about publication of manuscripts }\end{array}$ & 4.0 & $(0.6)$ \\
\hline $\begin{array}{l}\text { Peer review is important for research in } \\
\text { general }\end{array}$ & 4.8 & $(0.5)$ \\
\hline $\begin{array}{l}\text { Respondent's satisfaction with reviews } \\
\text { received for submitted manuscripts }\end{array}$ & 3.8 & $(0.7)$ \\
\hline
\end{tabular}

capacity in the developing world. Understanding the behaviour, perceptions and concerns of potential reviewers in small scientific communities may facilitate the identification of good reviewers and could also lead to the publication of studies relevant to international health.

\section{Ana MaruŠić \\ Darko Hren \\ Matko Marušić \\ Croatian Medical fournal \\ Zagreb University School of Medicine \\ Zagreb, Croatia \\ References \\ 1. Rochon PA, Mashari A, Cohen A, Misra A, Laxer D, Streiner DL, et al. Relation between randomized controlled trials published in lead- ing general medical journals and the global bur- den of disease. CMA7 2004;170(11):1673-7. \\ 2. Katic M, Juresa V, Oreskovic S. Family medi- cine in Croatia: past, present, and forthcoming challenges. Croat Med 7 2004;45(5):543-9. \\ 3. MaruŠić A, Lukic IK, MaruŚść M, McNamee D, Sharp D, Horton R. Peer review in a small and a big medical journal: case study of the Croa- tian Medical fournal and The Lancet. Croat Med 7 2002;43(3):286-9.}

DOI:10.1503/cmaj.1041755

\section{[Two of the authors respond:]}

A na Marušsić and colleagues have A identified another important factor contributing to the dearth of articles on leading causes of global death and disability in large Western medical journals, as described in our article. ${ }^{1}$ It is unfortunate that few faculty members at Croatian medical schools have published in or served as reviewers for one such journal, The Lancet. These researchers live in a country where the burden of disease is linked to the effects of war, and they could therefore make an important contribution to our understanding of this issue.

One way in which leading medical journals could improve representation of the global burden of disease would thus be to engage researchers in smaller countries such as Croatia, encouraging them to study important local issues such as the effects of war. Another would be to cultivate ties with smaller journals such as the Croatian Medical 